\title{
PENGARUH POSISI HIGH FOWLER 60 DAN 30 TERHADAP TEKANAN DARAH PADA PASIEN HIPERTENSI
}

\author{
Toto Subiakto*, Kusniawati*
}

\begin{abstract}
Abstrak
Hipertensi merupakan suatu penyakit yang bersifat kronis, tidak bisa disembuhkan dan hanya bisa dikontrol oleh pola hidup sehat dan obatobatan.Salah satu tindakan mandiri keperawatan guna mempertahankan oksigenasi adalahmengatur posisi pasien hipertensi. Pengaturan posisi dapat membantuvenous return jantung optimal sehingga dapat membantu meningkatkan cardiac output.Desain penelitian quasi eksperiment dengan pendekatan pre dan post test. Tujuan penelitian ini mengidentifikasi pengaruh posisi high fowler $60^{\circ}$ dan $30^{\circ}$ terhadap tekanan darah pada pasien hipertensi.Populasi adalah seluruh pasien hipertensi yang berobat di RSU Tangerang, jumlahsampel berjumlah 20 responden.Responden mendapat perlakuan posisi $60^{\circ}$ dan $30^{\circ}$ kemudian peneliti melihat perbedaan efektifitas terhadap tekanan darah pada subyek penelitian.Analisis statistik menggunakan dependent $t$ test.Hasil penelitian menunjukkan bahwa rata-rata tekanan darah sistolik sebelum perubahan posisi (supine) adalah 180,00 $\mathrm{mmHg}$ dengan standar deviasi 12,11 $\mathrm{mmHg}$. Rata-rata tekanan darah sistolik posisi high fowler $60^{\circ}$ adalah 182,81 dengan standar deviasi $17,017 \mathrm{mmHg}$, rata-rata perbedaan sistolik supine dan sistolik posisi fowler $60^{\circ}$ adalah2,81 mmHg dengan standar deviasi 16,018 $\mathrm{mmHg}$. Hasil uji statistik menunjukkantidak ada perbedaan yang signifikan rata-rata tekanan darah sistolik supine dan posisi high fowler $60^{\circ}(\mathrm{p}=0,493)$. Hasil uji statistik tidak ada perbedaan bermakna antara rata-rata tekanan darah sistolik maupun diastolik antara pasien hipertensi pada posisi supine, fowler $30^{\circ}$, dan high fowler $60^{\circ}$.Pelayanan keperawatan di rumah sakit diharapkan dapat melakukan pengaturan posisihigh fowler $60^{\circ}$ dan fowler $30^{\circ}$ pada pasien hipertensi dengan kondisi yang stabil.
\end{abstract}

Kata kunci: Hipertensi, posisi $60^{\circ}$, posisi $30^{\circ}$

\begin{abstract}
Hypertensionisa diseasewhichischronic, incurableandcan only becontrolledbya healthy lifestyleand medication. Independentnursingintervention tomaintainof patient's oxygenationis position of hypertension patient. Position canhelpthe optimal cardiac venous returnso that it can help improve cardiac output. This study aimed to identifythe effect of $60^{\circ}$ high fowler's positionand $30^{\circ}$ high fowler's positionon blood pressurein hypertensive patients. Research design was quasi experiment with pre and post test. The population was all hypertensive patients treated in RSU Tangerang. Sample size of 20 responden. Respondents received treatment position $60^{\circ}$ and $30^{\circ}$ then researchers looked atdifferences inthe effectiveness of the blood pressure. Statistical analysis used for this study was dependent $t$ test. The results showed that the average systolic blood pressure before the change in position (supine) was $180.00 \mathrm{~mm} \mathrm{Hg}$ with a standard
\end{abstract}


deviation of $12.11 \mathrm{mmHg}$.Averagesystolicbloodpressure of $60^{\circ} \mathrm{high}$ fowler's positionwas $182.81 \mathrm{mmHg}$ with a standard deviation of $17.017 \mathrm{mmHg}$, the average difference in supine systolic and systolic of $60^{\circ}$ high fowler positionwas $2.81 \mathrm{mmHg}$ with a standard deviation of $16.018 \mathrm{mmHg}$. Statistical test results showed no significant difference inmeansupinesystolicbloodpressureand $60^{\circ}$ high fowler'sposition( $\left.\mathrm{p}=0.493\right)$. The results ofstatistical testsnosignificantdifferencebetween the average systolic and diastolic blood pressure among hypertensi vepatientsin thesupine position, $30^{\circ}$ highfowler position and $60^{\circ}$ high fowler position. Nursing servicesinthe hospitalare expected toperform $60^{\circ}$ high fowler's positionand $30^{\circ}$ high fowler's positionin hypertensive patients with stable conditions.

\section{Keywords: Hypertension, position $60^{\circ}, 30^{\circ}$ position}

\section{Pendahuluan}

Hipertensi adalah merupakan suatu penyakit kardiovaskuler yang menjadi masalah utama kesehatan di masyarakat Indonesia dan negaranegara lain. Hipertensi merupakan salah satu penyakit kardiovaskuler menjadi menjadi tiga besar penyebab kematian di dunia (Cobanian, 2003). Hipertensi merupakan suatu penyakit yang bersifat kronis, tidak bisa disembuhkan dan hanya bisa dikontrol oleh pola hidup sehat dan obat-obatan (Beever, 2006).

Pada pasien hipertensi sekresi epinefrin dan nor epineprine akibat stres emosional atau mental bisa menurunkan kualitas hidup selain itu stres mental (psikososial) dapat meningkatkan tekanan darah (Jaret, 2008). Menurut penelitian dari The farmingham heart study meyakini bahwa individu yang memiliki tekanan darah normal pada usia 55 tahun memiliki resiko $90 \%$ untuk mendapatkan tekanan darah tinggi selama hidupnya (Departement of Health and Human Services, 2004). WHO mengemukakan bahwa individu yang memiliki tekanan darah normal pada usia 55 tahun memiliki resiko 90\% untuk mendapatkan tekanan darah tinggi pada usia 40-70 tahun, setiap peningkatan tekanan sistolik $20 \mathrm{mmHg}$ atau tekanan diastolik $10 \mathrm{mmHg}$ memiliki kemungkinan 2 kali mendapatkan penyakit kardiovaskuler pada saat tekanan darah melewati rentang 115/75 mmHg sampai dengan 
185/115 $\mathrm{mmHg}$ (Lewington, et al, 2002)

Perawat sebagai pemberi pelayanan kesehatan yang bertugas untuk memenuhi kebutuhan dasar manusia sangatlah diperlukan dalam upaya perawatan pasien dengan hipertensi sehingga kesehatan pasien dapat dioptimalkan kembali.Banyak permasalahankeperawatan yang dapat muncul pada pasien dengan hipertensi diantaranya adalahgangguan oksigenasi berhubungan dengan gangguan suplai oksigen akibatpeningkatan tekanan darah (Brunner \& Suddart, 2000) sehingga untuk mempertahankan oksigenasi tetap adekuat diperlukan tindakantindakan keperawatan yang tepat.Salah satu tindakan mandiri keperawatan guna mempertahankan oksigenasi adalahmengatur posisi pasien hipertensi. Pengaturan posisi dapat membantuvenous return jantung optimal sehingga dapat membantu meningkatkan cardiac output. Posisi yang tepat juga dapat meningkatkan relaksasi otot-otot tambahansehingga dapat menurunkan dispnea (Brunner \& Suddart, 2000).Hemodinamik merupakan indikator yang digunakan untuk mengetahui fungsi sirkulasi sistemik dalam tubuh yang terdiri dari pemantauan secara invasif dan non invasif.Pemeriksaan tekanan darah, denyut jantung, saturasi oksigen, respirasi dan suhu adalah pemeriksaan hemodinamik non invasif.

Pada keadaan kritis pasien dengan hipertensi membutuhkan penatalaksanaan baik farmakologis maupun non farmakologis dengan tujuan untuk menghilangkan gejala dan memperbaiki kualitas hidup.Hipertensi merupakan kondisi yang memerlukan penatalaksanaan yang tepat termasuk mengetahui penyebab, perbaikan hemodinamik dan perbaikan oksigenasi jaringan. Menempatkan penderita dengan posisi duduk dengan pemberian oksigen merupakan tindakan pertama yang dapat diberikan pada pasien hipertensi (Mariyono \& Santoso, 2007). Posisi merupakan salah satu faktor yang harus diperhatikan dalam menjaga sirkulasi sistemik yang adekuat karena dapat mempengaruhi sistem hemodinamik termasuk pada sistem vena.(Gelman, 2008). 
Menurut beberapa teori, perubahan posisi tubuh dapat mempengaruhi perubahan hemodinamik non infasif diantaranyatekanan darah,denyut jantung, saturasi oksigen dan frekuensi pernafasan (Kozier, erb; Berman \& Synder, 2004). Gelman (2008)menyatakan bahwa perbedaan posisi seperti head up dan head down mempunyai efek hemodinamik secara sistemik termasuk fungsi sistem vena. Hal tersebut didukung dengan penelitian lain yang menyatakan bahwa pada orang sehatsaat posisi head up dan head down dapat mempengaruhi tekanan darah dan perubahan pada tekanan vena sentral (Cicolini, Gagliardi \& Ballone, 2010; Eser, Khorshid, Gunes \& Denir, 2006; Lieshout, 2005).

Cicolini, et al (2010) menyatakan bahwa terjadi penurunan tekanan darah sistolik dan diastolik serta MAP (Mean Arterial Pressure) ketika dilakukan perubahan posisi pada orang sehat, dari posisi fowler menjadi posisi semifowler kemudian posisi supine dengan waktu 1 menit pada setiap posisi. Penelitian lain yang dilakukan oleh Zaidi, et al (1999), terhadap 20 orang sehat yang meneliti hal yang sama dengan waktu interval 2 dan 5 menit, menyatakan bahwa posisi head up $<60^{\circ}$ menghasilkan tekanan darah dan denyut jantung yang lebih rendah dibandingkan dengan posisi head up $>60^{\circ}$ dan posisi $60^{\circ}$ merupakan posisi paling tinggi yang tidak menghasilkan orthostatic stress. Penelitian ini juga menyatakan tidak ada perbedaan hasil penelitian pada interval 2 dan 5 menit.

Menurut Kozier (2008), posisi fowler atau head up dapat mempengaruhi kondisi hemodinamik seperti hipotensi postural akibat penurunan darah yang kembali ke jantung setelah perubahan posisi yang terlalu cepat, penurunan perfusi cerebral, penurunan MAP dan CVP akibat menurunnya venous return yang berdampak pada penurunan cardiac output (CO) hingga 20\%, terutama posisi head up $\geq 60^{\circ}$.

\section{TUJUAN PENELITIAN}

Tujuan umum penelitian ini adalah mengidentifikasi pengaruh posisi high fowler $60^{\circ}$ dan $30^{\circ}$ terhadap tekanan darah pada pasien hipertensi. Sedangkan tujuan khusus penelitian ini 
adalah mengetahui pengaruh posisi $60^{\circ}$ terhadap tekanan darah sistolik dan diastolik pada pasien hipertensi, mengetahui pengaruh posisi $30^{\circ}$ terhadap tekanan darah sistolik dan diastolik pada pasien hipertensi, dan membandingkan pengaruh posisi high fowler $60^{\circ}$ dengan $30^{\circ}$ terhadap tekanan darah pada pasien hipertensi.

\section{Metode Penelitian}

Desain penelitian ini menggunakan quasi eksperiment dengan pendekatan pre dan post test. Semua responden mendapat perlakuan posisi $60^{\circ}$ dan $30^{\circ}$ kemudian peneliti melihat perbedaan efektifitas terhadap tekanan darah pada subyek penelitian.Instrumen dalam penelitian ini menggunakan lembar observasi berupa format daftar isian untuk mencatat hasil pengukuran tekanan darah sistolik dan diastolik pada untuk posisi $60^{\circ}$ dan $30^{\circ}$.Populasi penelitian ini adalah semua pasien hipertensi yang berobat di Rumah Sakit Umum Tangerang.Sampel pada penelitian ini yaitu pasien hipertensi yang di rawat di ruang rawat inap dengan kondisi tekanan darah stabil dengan jumlah 20 orang.Teknik pengambilan sampel dalam penelitian ini dengan menggunakan teknikpurposive sampling yaitu memilih subyek penelitian yang ada pada waktupelaksanaan penelitian dan sesuai dengan kriteria inklusi (Arikunto, 2006; Notoatmodjo, 2007). Analisis data menggunakan ujidependent t test.

\section{Hasil dan Pembahasan}

Hasil penelitian univariat menjelaskan karakteristik, masing masing variabel yaitu: usia dan jenis kelamin, seperti dijelaskan pada tabel 1 dan 2 sebagai berikut:

Tabel 1. Distribusi responden berdasarkan usia di RSU Tangerang

\begin{tabular}{ccc}
\hline $\begin{array}{c}\text { Variabel } \\
\text { umur }\end{array}$ & $\mathrm{N}$ & Prosentase \\
\hline $50-60$ & 10 & $62,5 \%$ \\
$60-70$ & 4 & $25,0 \%$ \\
70 & 2 & $12,5 \%$ \\
\hline Total & 16 & 100 \\
\hline
\end{tabular}

Tabel 2. Distribusi responden berdasarkan jenis kelamindi RSU Tangerang

\begin{tabular}{ccc}
\hline $\begin{array}{c}\text { Variabel } \\
\text { jenis kelamin }\end{array}$ & $\mathrm{N}$ & Prosentase \\
\hline Perempuan & 11 & $68,75 \%$ \\
Laki-laki & 5 & $31,25 \%$ \\
\hline Total & 16 & 100 \\
\hline
\end{tabular}


Tabel 3

Analisa bivariat pada penelitian ini menggunakan uji $t$ dependen karena

Perbandingan rerata perubahan tekanan darah sistoliksupine dan post posisi $30^{\circ}$ dan $60^{\circ}$ di RSU Tangerang responden pada penelitian ini adalah kelompok yang sama. Sebelum dilakukan uji $\mathrm{t}$ terlebih dahulu dilakukan uji normalitas dengan menggunakan skewnes dibagi standar eror maka untuk hasil tekanan darah sistolik dengan

\begin{tabular}{|l|c|c|c|c|c|}
\hline $\begin{array}{c}\text { Varia } \\
\text { bel }\end{array}$ & $\begin{array}{c}\text { Pengukura } \\
\mathrm{n}\end{array}$ & Mean & SD & Min-Max & $\begin{array}{c}\mathrm{P} \\
\text { Value }\end{array}$ \\
\hline $\begin{array}{l}\text { Tek. } \\
\text { darah } \\
\text { sistoli } \\
\mathrm{k}\end{array}$ & fupine & 180,00 & 12,11 & $150-200$ & \\
& fowler 30 & 174,38 & 17,017 & $\begin{array}{c}140-200 \\
150-13,34\end{array}$ & \\
& perbedaan & 5,62 & 14,477 & $11,39-5,72$ & 0,141 \\
& fowler 60 & 182,81 & 19,746 & & \\
& perbedaan & 2,81 & 16,018 & & 0,493 \\
\hline
\end{tabular}

posisi supine didapatkan nilai 0,515/0,564 =0,913. $(<2)$ dapat dikatakan distribusi data normal.

Kemudian untuk data tekanan darah sistolik posisi fowler 30 derajat dilakukan uji normalitas 0,319/0,564 $=0,565$ dapat dikatakan distribusi normal $\quad(<2)$.maka dilakukan uji paired $t$ tes (uji parametrik).

Sedangkan untuk data tekanan darah sistolik high fowler 60 derajat dilakukan uji normalitas 0,28 /0,564 $=-496$ dapat dikatakan distribusi normal $(<2)$. Maka dilakukan uji paired t test (uji parametrik)

Hasil penelitian menunjukkan bahwa rata-rata tekanan darah sistolik sebelum perubahan posisi (supine) adalah 180,00 $\mathrm{mmHg}$ dengan standar deviasi 12,11 mmHg. Pada pasien setelah dilakukan perubahan posisi selama lima menit, rata-rata tekanan darah sistolik 30 derajat adalah 174,38 dengan standar deviasi 17,017 $\mathrm{mmHg}$. Sedangkan nilai mean perbedaan sistolik supine dan sistolik posisi fowler 30 derajat adalah $5,62 \mathrm{mmHg}$ dengan standar deviasi $14,477 \mathrm{mmHg}$. Hasil uji statistik didapatkan nilai $\mathrm{P}=$ 0,141 (2 tailed) maka dapat disimpulkantidak ada perbedaan yang signifikan rata rata tekanan darah sistolik supine dan posisi fowler 30 derajat. 
Hasil penelitian menunjukkan bahwa rata-rata tekanan darah sistolik sebelum perubahan posisi (supine) adalah $180,00 \mathrm{mmHg}$ dengan standar deviasi 12,11 mmHg. Pada pasien setelah dilakukan perubahan posisi selama lima menit, rata rata tekanan darah sistolik 60 derajat adalah 182,81 dengan standar deviasi 17,017 $\mathrm{mmHg}$. Sedangkan nilai mean perbedaan sistolik supine dan sistolik posisi fowler 60 derajat adalah $2,81 \mathrm{mmHg}$ dengan standar deviasi $16,018 \mathrm{mmHg}$. Hasil uji statistik didapatkan nilai $\mathrm{P}=$ 0,493 ( 2 tailed) maka dapat disimpulkan tidak ada perbedaan yang signifikan rata rata tekanan darah sistolik supine dan posisi high fowler 60 derajat.

Tabel 4. Perbandingan rerata perubahan tekanan darah diastoliksupine dan post posisi 30 dan 60 di RSU Tangerang
Analisis bivariat pada penelitian ini menggunakan uji $t$ dependen karena responden pada penelitian ini adalah kelompok yang sama. Sebelum dilakukan uji $t$ terlebih dahulu dilakukan uji normalitas dengan menggunakan skewnes dibagi standar eror maka untuk hasil tekanan darah diastolik dengan posisi supine didapatkan nilai $0,721 / 0,564=1,278$ (<2) dapat dikatakan distribusi data normal. Kemudian untuk data tekanan darah diastolik posisi fowler 30 derajat dilakukan uji normalitas 0,545/0,564 = 0,966 dapat dikatakan distribusi normal (<2). maka dilakukan uji paired $t$ tes (uji parametrik).Sedangkan untuk data tekanan darah diastolik high fowler 60 derajat dilakukan uji normalitas 0,846 $/ 0,564=1,5$ dapat dikatakan distribusi normal $(<2)$. Maka dilakukan uji paired t test (uji parametrik).

\begin{tabular}{|l|c|c|c|c|c|}
\hline $\begin{array}{c}\text { Varia } \\
\text { bel }\end{array}$ & $\begin{array}{c}\text { Penguku } \\
\text { ran }\end{array}$ & Mean & SD & $\begin{array}{c}\text { Min- } \\
\text { Max }\end{array}$ & $\begin{array}{c}\text { P } \\
\text { Val } \\
\text { ue }\end{array}$ \\
\hline $\begin{array}{l}\text { Teka } \\
\text { nan } \\
\text { darah } \\
\text { diasto } \\
\text { lik }\end{array}$ & $\begin{array}{c}\text { Supine } \\
\text { fowler } \\
30\end{array}$ & 105,63 & 11,53 & $90-13$ & \\
& $\begin{array}{c}\text { perbeda } \\
\text { an }\end{array}$ & 4,00 & 9,93 & $\begin{array}{c}1,29- \\
9,29\end{array}$ & 0,13 \\
& $\begin{array}{c}\text { fowler } \\
60\end{array}$ & 103,75 & 13,60 & $90-13$ & 0,38 \\
& $\begin{array}{c}\text { perbeda } \\
\text { an }\end{array}$ & 1,875 & 8,34 & $\begin{array}{c}5,27- \\
6,32\end{array}$ & \\
\hline
\end{tabular}


Hasil penelitian menunjukkan bahwa rata-rata tekanan darah diastolik sebelum perubahan posisi ( supine) adalah 105,63 $\mathrm{mmHg}$ dengan standar deviasi $11,529 \mathrm{mmHg}$. Pada pasien setelah dilakukan perubahan posisi selama lima menit, rata rata tekanan darah diastolik pada posisi fowler 30 derajat adalah 101,63 mmHg dengan standar deviasi 15,130 $\mathrm{mmHg}$. Sedangkan nilai mean perbedaan diastolik supine dan sistolik posisi fowler 30 derajat adalah $4,000 \mathrm{mmHg}$ dengan standar deviasi $9,933 \mathrm{mmHg}$. Hasil uji statistik didapatkan nilai $\mathrm{P}=$ 0,128 (2 tailed) maka dapat disimpulkan tidak ada perbedaan yang signifikan rata rata tekanan darah diastolik supine dan posisi fowler 30 derajat.

Hasil penelitian menunjukkan bahwa rata-rata tekanan darah diastolik sebelum perubahan posisi (supine) adalah 105,63 mmHg dengan standar deviasi $11,529 \mathrm{mmHg}$. Pada pasien setelah dilakukan perubahan posisihighfowler selama lima menit, rata rata tekanan darah diastolik 60 derajat adalah $103,75 \mathrm{mmHg}$ dengan standar deviasi 13,601 $\mathrm{mmHg}$.
Sedangkan nilai mean perbedaan diastolik supine dan diastolik posisi fowler 60 derajat adalah $1,875 \mathrm{mmHg}$ dengan standar deviasi $8,342 \mathrm{mmHg}$. Hasil uji statistik didapatkan nilai $\mathrm{P}=$ 0,383 ( 2 tailed) maka dapat disimpulkan tidak ada perbedaan yang signifikan rata rata tekanan darah diastolik supine dan posisi high fowler 60 derajat

\section{Pembahasan}

Pembahasan ini membahas tentang interpretasi dan diskusi hasil penelitian, keterbatasan penelitian, serta implikasi terhadap pelayanan keperawatan, pendidikan dan penelitian.

Hasil penelitian terhadap pasien masih dikontrol obat antihipertensi dengan dosis ringan bahwa pengaruh perubahan posisi terhadap penurunan tekanan darah sistolik terlihat tidak signifikan dengan nilai mean perbedaan sistolik supine dan posisi fowler 30 derajat adalah $5,62 \mathrm{mmHg}$ dengan standar deviasi 14,477 $\mathrm{mmHg}$. Hasil uji statistik didapatkan nilai $\mathrm{P}=$ 0,141 maka dapat disimpulkan tidak ada perbedaan yang signifikan rata rata tekanan darah sistolik supine dan 
post posisi fowler 30 derajat. hiperaktif (Andrew \& Raymond, Begitupun pada hasil uji statistik pada 2005).

posisi high fowler 60 derajat didapatkan nilai $\mathrm{P}=0,493$ maka dapat disimpulkan tidak ada perbedaan yang signifikan.

Tidak adanya pengaruh posisi Penyebab lain yang dapat mengakibatkan kurangnya respon pembuluh darah terhadap perubahan posisi adalah usia. Sebagian besar terhadap tekanan darah dapat responden terdiri dari dewasa madya disebabkan karena sampel yang kecil dan dewasa lanjut. Menurut Setianto (2007), dinding pembuluh darah karena pada penelitian ini tidak menjadi lebih kaku seiring memeperhitungkan variabel bertambahnya usia, karena pengganggu.Selain itu dapat bertambahnya jaringan ikat kolagen disebabkan oleh terapi farmakologis pada tunika media dan adventisia yaitu Terapi yang diberikan pada responden yang berpengaruh tekanan arteri sedang dan besar. Akibatnya tahanan pembuluh darah meningkat darah. Diantaranya, ACE I dan menjadi tidak flexible.

(angiotensin converting enzyme inhibitor) sebagian besar responden Posisi merupakan salah satu faktor menggunakan obat ini, ACE I, bekerja untuk menghambat enzim yang meningkatkan angiotensin II sehingga menghambat pengeluaran aldosteron yang dapat menyebabkan yang harus diperhatikan dalam menjaga sirkulasi sistemik yang adekuat karena dapat mempengaruhi sistem hemodinamik termasuk pada sistem vena.(Gelman, 2008).

vasokontriksi pada pembuluh darah sehingga tekanan darah dapat dipertahankan. Obat lain yang berpengaruh terhadap tekanan darah adalah beta blocker yang bekerja untuk menekan sistem simpatis atau sistem andrenergik pada keadaan

Menurut beberapa teori, perubahan posisi tubuh dapat mempengaruhi perubahan hemodinamik non infasif diantaranya, tekanan darah, denyut jantung, saturasi oksigen dan frekuensi pernafasan (Kozier, erb, 
Berman \& Synder, 2004). Gelman (2008) menyatakan bahwa perbedaan posisi seperti head up dan head down mempunyai efek hemodinamik secara sistemik termasuk fungsi sistem vena. Hal tersebut didukung dengan penelitian lain yang menyatakan bahwa pada orang sehat, saat posisi head up dan head downdapat mempengaruhi tekanan darah dan perubahan pada tekanan vena sentral (Cicolini, Gagliardi \& Ballone, 2010; Eser, Khorshid, Gunes \& Denir, 2006; Lieshout, 2005).

\section{Simpulan}

Simpulan dari hasil penelitian dan pembahasan diatas maka didapakan bahwa:Tidak ada pengaruh secara signifikan perubahan dari posisi supine terhadap penurunan tekanan darah sistolik dan diastolik pada pasien hipertensi walaupun secara medis penurunan tekanan darah masih diatas normal, tidak ada pengaruh signifikan perubahan posisi fowler 30 derajat terhadap penurunan tekanan darah sistolik dan diastolik pada pasien hipertensi, tidak ada pengaruh sinifikan perubahan posisi high fowler 60 derajat terhadap penurunan tekanan darah sistolik dan diastolik pada pasien hip[ertensi walaupun secara penurunan tekanan darah masih diatas normal, tidak ada perbedaan signifikan antara rata-rata tekanan darah sistolik maupun diastolik antara pasien hipertensi pada posisi supine, posisi fowler 30 derajat, dan posisihigh fowler 60 derajat.

\section{Daftar Pustaka}

Argstatter H,.\& Haberbosch W, Bolay H.V. (2006). Study of the effectiveness ofmusical stimulation during intracardiac catheterization. Clin Res Cardiol. 2006Oct;95(10):511-3.

\section{Beever.D.G., (2006). Understanding Blood Pressure(http://www. familydoctorco.id.uk/onlinebo oks/Blood\%20pressure.pdf)}

Badr, C., Elkins, M. R., \& Ellis, E. R. (2002). The effect of body position on maximal expiratory pressure and flow. Australian Journal of Physiotherapy .The University of Sydney 2Royal Prince Alfred Hospital, Sydney, 48.

BB.Sramek. (2002). Systemic Hemodynamics and Hemodynamic Management. InstantPublisher.com

Cicolini, G., Gagliardi, G., \& Ballone, E. (2010). Effect of 
Fowler's Body Position on Blood Pressure Measurement. [Research in Brief]. Journal of Clinical Nursing, 19, 35813583.

Cobanian, A.V., Bakris, G.L., Back, H.R.,et al. (2003). The Seventh Report of the JointNational Committee on Prevention, Detection, Evaluation, and Treatment ofHigh Blood Pressure: The JNC 7 Report(erratum in: Journal of the AmericanMedical Association, 2003; 290(2):197). Journal of the American Association

Cushman, M. J. \& Hoffman, M. J., (2004). Complementary and Alternative HealthCare and the Home Care Population. Home Health Care Management danPractice /August 2004/Volume 16, Number 5, 360- 373.

Dorbyk A. A., (2007). Meditation to Relieve Stress: The Connection between MindandBody. ttp://www.selfgrowth.com/arti cles/Dorbyk4.html

Gelman, S. (2008). Venous Function and Central Venous Pressure. [Review article]. Anaesthesiology, 108, 735-748.

Guyton, A. C., \& Hall, J. E. (2008). Texsbook of medical Physiology.

Smeltzer, S.C., Bare., B.G., Hinkle, J.L.\& Cheever, K.H.,(2008). Textbook ofMedical -Surgical Nursing. Eleventh edition. Brunner,\& Suddarth's. Philadhelpia
Lippincott Williams \& Wilkins, a Wolter Kluwer bussiness 